\title{
Türkiye'de Vergi Esnekliğinin Panel Eşbütünleşme ve Nedensellik Testleri ile Analizi
}

\author{
DOI: 10.26466/opus.848755 \\ $*$ \\ Zerife Yıldırım* - Murat Demir ** \\ * Dr.Öğr.Üyesi, Harran Üniversitesi, İ̈BF, Ekonometri Bölümü \\ E-Posta: zerifeyildirim@gmail.com \\ ORCID: 0000-0002-2478-2823 \\ ** Prof.Dr., Harran Üniversitesi, İ̈BF, Maliye Bölümü \\ E-Posta: mdemir@harran.edu.tr \\ ORCID: 0000-0002-1466-1104
}

\begin{abstract}
Öz
Bu çalışmanın amacı Türkiye'de 2004-2019 yıllarını kapsayan dönemler için İstatistiki Bölge Birimleri Sinıflandırması (IBBS 2) Düzey 2'ye göre vergi esnekliğini incelemektir. Bu amaçla İkinci Nesil Birim Kök Testleri, Westernlund Eşbütünleşme ve Dumitrescu Hurlin Panel Nedensellik Testleri kullanılmıştır. Analiz sonuçları ekonomik büyüme ve vergi gelirleri değişkenlerinin uzun dönemde eşbütünleşme ilişkisine sahip olduğunu göstermektedir. Panel DOLSMG test sonucuna göre ise Panel genelinde vergi gelirleri için esneklik katsayısı 0.17 olarak hesaplanmıştır. Bu sonuca göre ülke geneli 26 bölge için, ekonomik büyümedeki \%1'lik artış vergi gelirlerinde uzun dönemde \%0.17' lik bir artış meydana getirmektedir. Bu esneklik değeri oldukça düşük bir niteliktedir ve vergilemenin gelir sağlayıcı özelliğini yerine getirememektedir. Vergi esneklĭgini IBBSS-Düzey 2' ye göre incelediğimizde ise 26 bölge içinden; TRA2, TRC1, TRC3, TR22, TR32, TR41, TR63 ve TR82 bölgelerine ait katsayı sonuçları 1'in üzerinde, pozitif ve istatistiksel olarak anlamlı çıkmıştır. Dumitrescu Hurlin panel nedensellik analizinde panel geneli için ekonomik büyümeden vergi gelirlerine doğru nedensellik ilişkisi olduğu ve yine vergi gelirlerinden ekonomik büyümeye doğru nedensellik ilişki olduğu görülmüştür. Yani değişkenler arasında çift yönlü bir nedensellik ilişkisi olduğunu ifade etmek mümkündür.
\end{abstract}

Anahtar Kelimeler: Vergi Esnekliği, Ekonomik Büyüme, Panel Eşbütünleşme, Ortalama Grup Dinamik Stralı En Küçük Kareler (DOLSMG), Dumitrescu Hurlin Panel Nedensellik 


\title{
Analysis with Panel Cointegration and Causality Tests of Tax Elasticity in Turkey
}

\begin{abstract}
The purpose of this study is examine for Turkey for periods covering the years 2004-2019 according to the Classification of Statistical Territorial Units (IBBS 2) Level 2 of tax flexibility. For this purpose, Second Generation Unit Root Tests, Westternlund Cointegration and Dumitrescu Hurlin Panel Causality Tests are used. The results of the analysis show that the variables of economic growth and tax revenues have a long-term cointegration relationship. According to the panel DOLSMG test result, the elasticity coefficient for tax revenues across the panel was calculated as 0.17. According to this result for 26 regions across the country, 1\% increase in economic growth creates an increase $0.17 \%$ in tax revenues in the long run. This elasticity value is of a very low quality and cannot fulfill the income generating feature of taxation. When we examine the tax flexibility according to NUTS-Level 2, among 26 regions; the coefficient results of TRA2, TRC1, TRC3, TR22, TR32, TR41, TR63 and TR82 regions were over 1, positive and statistically significant. In Dumitrescu Hurlin panel causality analysis, there is a causality relationship from economic growth to tax revenues for the panel in general, and again it is seen that there is a causal relationship from tax revenues to economic growth. In other words, it can be stated that there is a bidirectional causality relationship between variables.
\end{abstract}

Keywords: Tax Flexibility, Economic Growth, Panel Cointegration, Dynamic Ordinary Least Squares Mean Grup(DOLSMG), Dumitrescu Hurlin Panel Causality. 


\section{Giriş}

Belli bir dönemde vergi gelirlerinde gerçekleşen yüzde değişimin, ayn dönemin gayrisafi yurtiçi hasılasında(GSYH) gerçekleşen yüzde değişime oranı vergi esnekliği olarak ifade edilir. Vergi gelirlerinin gayrisafi milli hasıladaki değişmelere karşı gösterdiği duyarlılığı ifade eden vergi esnekliği; konusu, iktisadi, mali ve sosyal yönleri ile vergi teorisyenlerinin üzerinde önemle durdukları bir çalışma alanı olmaktadır.

Vergi esnekliğindeki gerçekleşmeler hem kısa dönem dalgalanmaların hem de uzun dönem büyüme eğiliminin bir göstergesi olarak değerlendirilmektedir. Vergi esnekliği, kısa dönemde konjonktürel dalgalanmalara bağlı olarak GSYİH'da meydana gelen değişmelerin vergi gelirlerini ne düzeyde etkilediğini, vergi gelirlerine ne düzeyde yansıdığını gösterirken, uzun dönemde ise GSYİH artışının yıllar içinde vergi gelirlerini ne düzeyde etkilediğini, vergi gelirlerine ne düzeyde yansıdığını göstermektedir (Russell ve Randall, 2007, s.550). Konjonktürel olarak ekonomide yaşanan gerçekleşmelere, vergi gelirleri de esas itibariyle paralel bir seyir izlemektedir. Bununla birlikte konjontürün vergi sistemini oluşturan her bir vergi üzerinde yaptığı etki tamamen farklı nitelikte olmaktadır. Verginin konjonktürel esnekliğinin belirlenebilmesi için öncelikle verginin gelir esnekliğinin hesaplanması gerekmektedir. Verginin gelir esnekliği, vergi gelirlerinde gerçekleşen nispi değişiklik ile milli gelirde gerçekleşen nispi değişiklik arasındaki oran olarak ifade edilmektedir (Turhan, 1987, s. 318).

Vergi Esnekli $\breve{g} i=\frac{\Delta \text { Vergi }}{\Delta \text { Gelir }}=\frac{\frac{T_{t}-T_{t-1}}{T_{t-1}}}{\frac{Y_{t}-Y_{t-1}}{Y_{t-1}}}$

Söz konusu ilişki yukarıda denklem 1'de verildiği gibi ifade edilmektedir. Burada $\left(T_{t}\right)$ ve $\left(Y_{t}\right)$ içinde bulunulan dönem değerlerini, $\left(T_{t-1}\right)$ ve $\left(Y_{t-1}\right)$ ise bir önceki dönemde elde edilen değerleri göstermektedir. Söz konusu bu değerler her bir vergi için bulunabileceği gibi tüm vergi sistemi için de hesaplanabilir. Vergi gelirlerinin esneklik değeri bir verginin vergi mevzuatında değişiklik yapılmaksızın konjontürün genişleme dönemlerinde yüksek, daralma dönemlerinde ise düşük bir gelir sağladığını gösterir. Gelir esnekliği yüksek olan bir verginin otomatik olarak konjonktürel istikrarı sağlayıcı etkisinin 
kuvveti ayrıca bu verginin sağladığı gelirin yüksekliğini de bağlıdır. Sözgelimi gelir esnekliği çok yüksek olan bir verginin toplam vergi gelirleri içindeki payının düşük olması ve dolayısıyla bu verginin genel ekonomik yapı üzerinde oluşturacağı etkinin sınırlı olması bu verginin otomatik istikrar sağlayıcı niteliğini tartışmalı hale getirecektir. Bu nedenle esnekliğin niteliğini, etki alanı ve gücünü tam olarak görebilmek için vergi gelirlerinin esnekliğinin yanı sıra vergi esnekliğinin de hesaplanması gerekmektedir. Bir vergi gelirinde gerçekleşen değişikliklerin aynı dönem için milli gelirde gerçekleşen değişikliklere oranı olarak ifade edilen vergi esnekliği bir takım faktörlere göre şekillenmektedir.

Bir verginin gelir esnekliğini açıklayan önemli unsurlar vergi matrahının konjonktürel gelişmelere ne kadar bağlı olduğu ve milli gelirdeki değişimlere nasıl tepki verdiği olarak belirtilebilir. Bir diğer faktör, ilgili verginin tarife yapısıdır. Artan oranlı bir tarifeye sahip bir vergi tek oranlı bir vergiye göre konjonktürel gelişimi çok daha yüksek düzeyde gerçekleşir. Verginin tahakkuku ve tahsili arasındaki zaman da ilgili verginin esnekliğini belirleyen bir diğer etkendir. Verginin borcunun doğumu ile tahsili arasında uzun bir zaman diliminin olması ilgili süre zarfında konjonktürel etkinin azalmasına ve tahsil döneminde verginin vereceği tepkinin hiçbir etkisinin olmamasına hatta beklenmedik etkilerin ortaya çımasına neden olmaktadır.

\section{Türkiye'de Vergi Gelirleri ve Vergi Esnekliği}

Türk vergi sistemine göre, gelire dayalı vergiler, harcamalara dayalı vergiler ve mülkiyete dayalı vergiler toplam vergi gelirlerini oluşturmaktadır. Gelire dayalı vergilerin konusunu, gerçek kişi kazancı ve kurum kazancı olmak üzere iki unsur oluşturmaktadır. Harcamalara dayalı vergilerin konusunu; katma değer vergisi, özel tüketim vergisi, banka ve sigorta muameleleri vergisi, özel iletişim vergisi, şans oyunları vergisi, uluslararası ticaret ve muamelelerden alınan vergiler, damga vergisi ve harçlar oluşturmaktadır. Mülkiyete dayalı vergilerin konusunu ise; emlak vergisi, motorlu taşıtlar vergisi, veraset ve intikal vergisi oluşturmaktadır (Akar, 2013, s. 31-32).

Daha genel bir sınıflama ise dolaysız ve dolaylı vergiler şeklinde yapılabilir. Buna göre dolaysız vergiler olarak gelir ve mülkiyet üzerinden alınan vergiler gösterilebilir. Dolaylı vergiler ise, harcamalar üzerinden alınan vergiler 
olarak gösterilebilir. Bu ifade ile incelendiğinde Türkiye için toplam vergi gelirleri oransal olarak \%65 dolaylı vergiler, \%35 ise dolaysız vergilerden oluşturmaktadır (Çulha, 2012, s. 2).

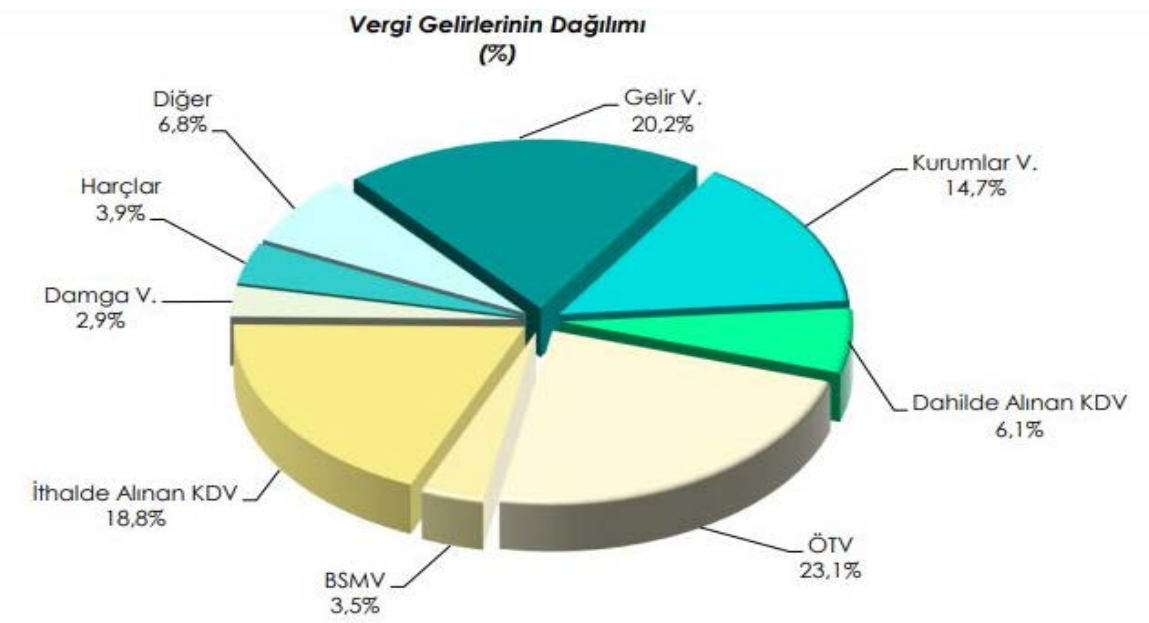

Şekil 1. Türkiye'de Toplam Vergi Gelirlerinin Dağılımı (2020 Yılı Ocak-Haziran Gerçekleşmelerine Göre) (Bingöl, 2020).

Şekil 1.' de 2020 yılı Ocak-Haziran dönemi için Türkiye'de toplam vergi gelirlerinin vergi türleri itibariyle dağılımı verilmiştir. Türkiye'de iç talepte meydana gelen değişmelerin vergi gelirleri üzerindeki etkisi oldukça yüksektir ve bu dağılım dönemin koşullarına göre değişebilmektedir.

Vergi türleri itibariyle esneklik değerleri incelendiğinde esnekliği en yüksek olan verginin kişisel gelir vergisi olduğu söylenebilir (Turhan, 1987, s. 320). Vergi gelirleri artan oranlı tarife yapısı ile konjonktürün genişleme dönemlerinde vergi matrahından daha hızlı artmaktadır. Buna karşın konjonktürün daralma dönemlerinde ortalama vergi oranlarında bir düşme olduğu için yükümlüler kullanabilir gelirlerindeki azalmaya rağmen tüketim ve yatırım harcamaların devam ettirebilmektedirler.

Artan oranlı tarifenin seyri kişisel gelir vergisinin esnekliği üzerinde belirleyici olan önemli bir unsurdur. Gelir tanımına nelerin girdiği, bunların konjonktürel dalgalanmalara karşı ne denli tepki verdiği de vergi esnekliği üzerinde belirleyici olmaktadır. Bir vergi sisteminde muafiyet ve istisnaların kapsamının çok geniş olması vergi esnekliğini olumsuz etkilemektedir. 
Kurumlar vergisinin esnekliği kişisel gelir vergisinin gerisindedir. Zira kurumlar vergisinin konusu gelir vergisine göre çok daha dardır. Ancak ekonomik büyüme ile birlikte kurum kazançlarının artması veya daralma ile kurum kazançlarının azalması ve bunların kurumların vergi yükümlülüklerine yansıması kaçınılmazdır.

Gider vergilerine bakıldığında ise genel bir muamele vergisinin esnekliğinin yüksek olduğu söylenebilir. Zorunlu ihtiyaç maddelerinin vergiden istisna edilmesi durumunda söz konusu esneklik çok daha yüksek düzeyde olacaktır. Özel tüketim vergilerinde de vergi kapsamına giren mallara göre esneklik düzeyi değişmektedir. Talep esnekliği sert olan zorunlu mallardan alınan özel tüketim vergilerin esnekliği düşük olurken lüks mallardan alınan özel tüketim vergilerinin esnekliği çok daha yüksektir.

Servet vergilerinin esnekliği konusunda da belirleyici olan husus yine ilgili verginin yani servetin kaynak itibariyle bileşimi ve dağılımıdır. Servet kapsamında menkul değerlerin payı ne denli çok olursa servet vergilerinin esnekliği de o denli yüksek olur.

Sistemin bütünü bakımından vergi muafiyet ve istisnaların kapsamının çok geniş olması da özellikle kişisel gelir vergisinin esnekliği üzerinde baskı yaratmaktadır (Kopczu, 2005, s. 2093).

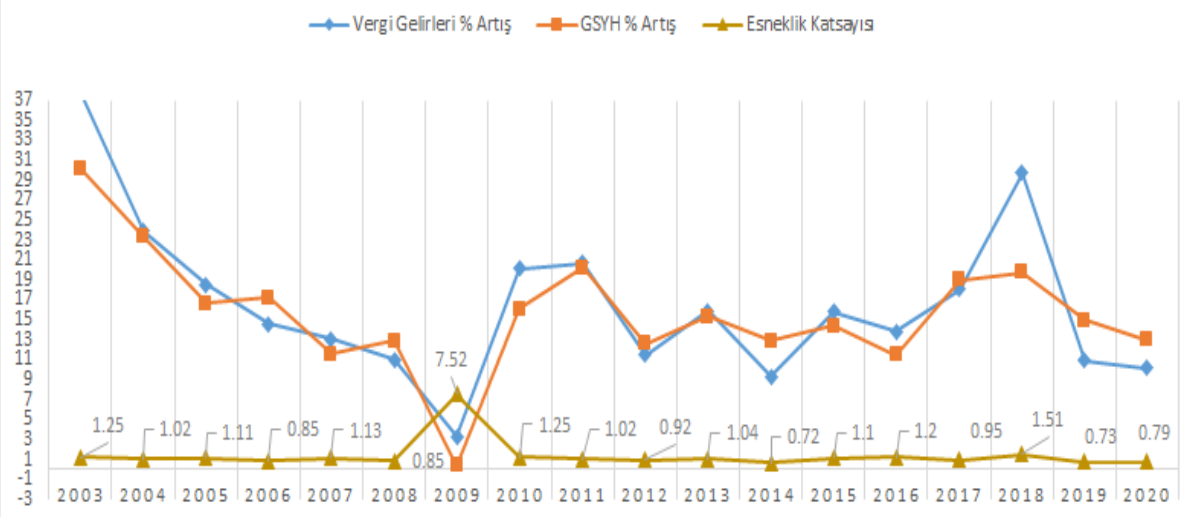

Şekil 2. Yillara Göre Türkiye'de Vergi Esneklik Katsayılarn

Şekil 2.' deki bilgiler incelendiğinde, Türkiye'de yıllara göre vergi esneklik katsayıları genel itibariyle 1'in etrafında değerler olarak gerçekleşmektedir. Ancak son yıllardaki değerlere göre 1' in altında kaldığ gözlemlenmektedir. 
Vergi esneklik katsayısı "1"'den büyük olduğu durumda verginin gelir sağlayıcı etkisi yüksek olmakta ve gelir artışı sağlanmaktadır. Vergi esneklik katsayısı "1"'den küçük olduğu durumlarda ise verginin gelir sağlayıcı etkisinin düşük olmasına neden olmaktadır. Literatürde vergi esnekliği ve esneklik katsayısı sonuçlarına göre bir çok çalışma bulunmaktadır.

Farklı ülkeler üzerine yapılan çalışma sonuçlarına bakıldığında, Hollanda da kısa ve uzun dönem vergi esneklikleri KDV için 1'e yakın çıarken kişisel gelir vergisi esneklikleri uzun dönem 1'in altında, kısa dönem 1'in üzerinde çıkmıştır (Bettendorf ve Van Limbergen, 2013, s. 256).

Romanya için 2001-2012 dönemini kapsayan bir çalışmada ise, Romanya'da vergi esnekliğinin tüm vergiler dikkate alındığında $A B$ ortalamasının altında olduğu saptanmıştır. Romanya'da en yüksek vergi esnekliği tüketim vergilerinde söz konusu olup esneklik katsayısı 1.47'dir. Bu oran $\mathrm{AB}$ ortalaması olan 0.19 'un üzerindedir. Dolaysız vergilerin esneklik katsayısı ise 1.20 olup $\mathrm{AB}$ ortalaması olan 2.1'in çok gerisindedir. Benzer özelliklere sahip incelenen çalışmalar, vergi esnekliğine yön veren çok sayıda değişken olduğunu, ortak değişkenler üzerinden bir esneklik derecesinin belirlenmesinin mümkün olmadığını göstermektedir. Aynı ülke için yapılan çalışmalarda bile dönemler arası yapılan hesaplamalarda aynı vergi çeşitlerine dair esneklik katsayılarının birbirinden oldukça farklı çıktığı görülmüştür (Bunescua ve Comaniciu, 2013, s. 614).

2001-2013 dönemi AB ülkeleri üzerine yapılan bir panel data çalışmasında konjoktürel dalgalanmalara hangi vergilerin doğrudan bir tepki verdiği görülmeye çalışılmış özellikle kurumlar vergisinin ve sonrasında kişisel gelir vergisinin diğer vergilere göre çok daha güçlü tepki verdikleri ve dolayısıyla esnekliklerinin daha yüksek olduğu görülmüştür (Mourre ve Princen, 2015, s.2).

$\mathrm{AB}$ ölçeğinde yapılan bir diğer çalışmada milli gelir ve vergi geliri arasındaki ilişkinin niteliği incelenerek kısa dönem uzun dönem vergi esnekliği hesaplanmaya çalışılmıştır. Kısa dönem vergi esnekliğinin konjonktürel dalgalanmalara göre değiştiği saptanmıştır. 1980-2013 arası 15 AB ülkesi verileri üzerinden yapılan analizde ekonominin resesyon ve genişleme dönemlerinde vergi esnekliklerinin farklı çıktığı belirlenmiştir. Dolaylı vergiler ve kurumlar vergisinde resesyon dönemlerinde esneklik daha yüksek düzeydedir. Genişleme ve resesyon dönemlerinde kişisel gelir vergisinin esnekliği ise daha 1lımlı bir düzeydedir (Boschiab ve d'Addona, 2017, s. 2). 
Özmen (2016), çalışmasında BRIC-T (Brezilya, Rusya, Çin, Hindistan ve Türkiye) ülkeleri için vergi gelirlerinin belirleyicilerini araştırmıştır. 19962013 yılları arası dönem için vergi gelirleri ile bunu açıklamaya yönelik değişkenleri arasındaki ilişkiyi panel eşbütünleşme analizi ile incelemiştir. Analizlerde kullandığı değişkenlerin vergi gelirleri üzerinde belirleyici olduğu sonucuna ulaşmış, eşbütünleşme ilişkisinin varlığ görülmüştür. Ancak bu ilişki katsayıları 1'den küçük çıktığı için elastik bir durum sağlanamamıştır. Kullanılan değişkenlerden; vergi gelirleri üzerinde KBGSYH, kurumlar vergisi gelirleri, enflasyon, ekonomik özgürlükler ve ticari serbestleşme ile yolsuzluklar vb. sayılabilir. Analiz sonuçlarındaki etkiler anlamlı ve tutarlı bulunurken, politik istikrar ile tarımsal kesim katma değer vergisi değişkenleri arasındaki analiz sonuçlarında sağlanan etkiler anlamsız bulunmuştur.

Akar ve Şahin (2015), Türkiye'de vergi canlılığının analizi adlı makalelerinde değişken olarak merkezi bütçe vergi gelirleri ve sanayi üretim endeksi serilerini kullanarak 2005-2014 dönemine ait aylık veri setleri ile çalışışlardır. Ekonometrik analizlerde vergi sisteminin canlılığını belirlemek için eşbütünleşme ve hata düzeltme modelini kullanmışlardır. Çalışmada yer alan analizlere göre, vergi sisteminin kısa dönem için otomatik istikrar sağlayıcı özelliğinin olmadığını, diğer taraftan uzun dönem için büyüme artışına dair mali sürdürülebilirliği olumlu yönde etkilediğini belirtmişlerdir.

Şimşek (2013), Türkiye üzerine yaptığı çalışmasında vergi esnekliği, vergi canlılığı ve vergi gayreti değişkenlerini kullanarak bölgesel düzeyde panel veri yöntemini çalışmıştır. Türkiye İsatatistiksel Bölge Birimleri Sınıflaması-2 (İBBS-2)' ye göre 2004-2008 dönemi tüm vergi türleri için araştırmanın yapıldığı çalışmada vergi esnekliğinin yeterince duyarlı olmadığı ve katsayı sonuçlarının da $1^{\prime}$ in altında kalarak inelastik özellik gösterdiği sonucuna ulaşılmıştır. Model tahminlerinde kontrol değişken olarak kullanılan sanayi değişkeninin vergi gelirlerinde sınırlı düzeyde artış sağlamış olması bile yeterinde duyarlılık oluşturmamıştır.

Akar (2013), Türkiye'de vergi esnekliğini 2007-2012 dönemi için aylık verilerle analiz etmiştir. Analiz kapsamında iki model üzerinde çalışılmış olup ilk modelde logaritmik model sonucu vergi esneklik katsayısı araştırılmış, ikinci modelde ise kısa dönem etkiler için hata düzeltme modeli kurulmuştur. Ayrıca gelir yerine sanayi üretim endeksi değişken olarak kullanılmış olup yorumlamalarda gelir etkisi olarak değerlendirilmiştir. Bu modellerden 
ilk modelde gelirdeki artışlar karşısında vergi gelirlerinin esnekliği belirlenirken, ikinci modelde kısa dönem vergi gelirleri ile konjonktürel değişimler ve istikrarı ölçen değişim modeli oluşturulmuştur. Analiz sonuçlarında uzun dönemde vergi gelirlerinin esnek olduğu sonucuna, kısa dönem model sonuçlarında ise vergi gelirlerinin istikrarsız bir yapıya sahip olduğu sonuçlarına ulaşılmıştır.

Hepaktan ve Çınar (2011), OECD ülkeleri üzerine yaptıkları çalışmalarında vergi esnekliğini panel eşbütünleşme testlerini kullanarak analiz etmişlerdir. KBGSYH ile vergi gelirleri arasındaki ilişkiyi 1989-2008 dönem için incelemişlerdir. Analizlerde yatay kesit bağımlılığı bulunmadığı için birinci nesil panel birim kök testlerinden Levin-Lin ve Chu (LLC), Breitung, Im-Pesaran ve Shin-(IPS), Fisher AD, Fisher PP ve Hadri uygulanmıştır. Eşbütünleşme sınaması için Pedroni, Kao, Johansen-Fisher ve Westerlund eşbütünleşme testleri ve DOLS tahmincisi ile de uzun dönem katsayıları üzerinden bulgular araştırılmıştır. Analiz sonuçlarına göre, uzun dönemde kişi başına gelir ve vergi gelirleri arasında 0.3 ile 0.5 değer aralıklarında eşbütünleşme ilşkisi olan uzun dönem katsayı etkilerine ulaşılmıştır. Buna göre gelirdeki 1 birimlik artış karşısında uzun dönemde vergi gelirleri de 0.3 birim ve 0.5 birim arasında pozitif doğrusal bir artışla etkilenmektedir. Ancak katsayı 1'den küçük olduğu için OECD ülkelerinde vergi esnekliği katsayısının inelastik olduğu, yani esnek olmadığı değerlendirmesi yapılmıştır.

Ertürk, Avşar ve Bulut (2009), Türkiye üzerine yaptıkları çalışmalarında devlet uygulamalarının vergi gelirleri üzerindeki etkilerini incelemişlerdir. $\mathrm{Bu}$ amaçla vergi gelirleri ile toplam vergi gelirlerini, kurumlar vergisi gelirlerini, katma değer vergisi gelirlerini ve gayri safi milli hasılayı analiz etmişlerdir. Analizlerde ve model sonuçları yorumlamalarında daha çok vergi canlılığı ve vergi esnekliği arasındaki farklılığa dikkat çekerek esneklikten ziyade vergi canlılık kavramının yerindeliğini tartışmışlardır. Türkiye' de 1981-2006 yılları için zaman serisi olarak kullanılan verilerin durağanlık araştırması yapıldıktan sonra tahmin edilen regresyon model sonuçları yorumlanmıştır.

Kuştepeli ve Şapçı (2006), Türkiye'de 1975-2005 dönemi için Johansen eşbütünleşme testlerini kullandıkları çalışmalarında gelir vergisi esnekliğini 0.95 olarak hesaplamışlardır. Yaklaşık olarak birim esnekliğe yakın olan bu değer, gelir artışının gelir vergisinde de yaklaşık oranlı bir artış sağladığı yönünde yorumlamada bulunmuşlardır. 
Skeete vd. (2004), Engle granger, eşbütünleşme testleri ve hata düzeltme modeli kullanarak vergi esnekliğini Bardados için araştırmışlardır. Çalışmaya göre, gayri safi hasıladaki değişikliklere vergi rejimi esneklik katasyısı uzun vadeye göre kısa vadede daha duyarlı sonuçlar vermektedir.

Yüce (2004), Kırgızistan vergi sistemi ve vergi esnekliği üzerine çalıştığ1 araştırmasında, vergi esneklik katsayısının genellikle 1'in altında olduğunu ve bu durumun vergi gelirlerinin düşük düzeyde olduğunun göstergesi olduğunu belirtmiştir. Ülkedeki vergi sisteminin gelir sağlama fonksiyonu yetersiz kalırken, aynı zamanda vergi sisteminin işlevselliğindeki konjonktürel istikrar sağlayıcı özelliğinin de yetersiz olduğunun göstergesi olarak kabul edilmiştir.

Mukarram (2001), Pakistan 1981-2001 dönemine dair çalışmasında vergi esnekliği katsayısının yeterince yüksek olmadığı sonucuna varmıştır. Pakistan için benzer bir çalışmayı Bilquees (2004)' de yapmıştır. Yapılan reformların Pakistan'da önemli bir gelir artısını sağlamadığını ve milli hasılada vergi esnekliği katsayısının birin altında olduğu sonucuna varmıştır.

Chipeta (1998), Malavi için 1970-1994 dönemi üzerine vergi reformları ve verimlilik arasındaki ilişkiyi incelemiştir. Çalışmasında vergi esneklik katsayısını 0.6 olarak bulmuştur. Edinilen sonuçlarla vergi tabanının milli hasıladan daha az büyüdüğü sonucuna ulaşılmıştır.

Kusi (1998), Gana'da vergi reformu ve bunun getiriler üzerine etkilerini incelemiştir. Çalışmasına göre vergi reformundan önce esneklik katsayısı 0.71 iken reform sonrasında bu esneklik katsayısı 1.22 olarak çok daha yüksek düzeyde gerçekleşmiştir. Ancak Gana üzerine benzer bir çalışma yapan Twerefou, Fumey, Assibey ve Asmah (2010) kısa dönem için yeterince yüksek bir vergi esnekliği katsayısı olmadığı sonucuna varmışlardır. Uzun dönemde vergi esnekliği katsayısı 1'den büyük çıkmış ve gelire karşı duyarlı olduğunu göstermiştir. Uzun vadede canlı ve esnek bir vergi sisteminden söz edilebilir. Ancak kısa dönem için böyle bir gerçekleşmenin söz konusu olmadığını belirtmişlerdir.

Osoro (1993) Tanzanya için 1979-1989 dönemine dair vergi reformlarının gelir artışı üzerine etkilerini incelediği çalışmasında, vergi esneklik katsayısını 0.76 olarak hesaplamıştır. Bu elastikiyet değeri ile vergi reformlarının istenen gelir artışını sağlayamadığı sonucuna ulaşmıştır. Osoro (1995) 'de ise 
1970-1980 dönemine dair bir veri seti kullanarak ele aldığ çalışmasında, genel vergi sistemi esnekliğini 1970 'te 0.85 olarak ve 1980 ' de ise 0.78 olarak, gelir vergisindeki esnekliğin azaldığını belirtmiştir.

Choudhry (1979) ABD, İngiltere, Malezya ve Kenya için vergi gelirlerinin esnekliğini incelemiştir. ABD ve İngiltere için esneklik katsayılarını sırasıyla 1.04 ve 1.24 olarak bulmuştur. Ancak Malezya ve Kenya için yaptığı araştırmasında esneklik katsayılarını sırasıyla 1.57 ve 1.32 olarak daha yüksek bulmuştur. Bu durumu o dönem için ABD' de ve İngiltere' de uygulanan politikaların gelirlerin azalmasına neden olduğu ve daha düşük esneklik değerlerine sebep olduğu şeklinde yorumlamıştır.

\section{Yöntem}

Çalışmada Türkiye için İstatistiki Bölge Birimleri Sınıflandırması (IBBS) Düzey 2'ye göre Kişi Başına Gayri Safi Yurtiçi Hasıla (KBGSYH) ile Vergi Gelirleri (VG) değişkenleri arasındaki uzun dönemli ilişki ve dinamik nedensellik ilişkisi analiz edilecektir. Bu kapsamda ilk olarak, çalışmada yer alan değişkenlere ait serilerin durağanlık araştırmasında kullanılacak yöntemi belirlemek amacıyla yatay kesit bağımlılı̆̆ testi yapılacak ve katsayıların homojenlik durumu araştırılacaktır.

Panelin zaman boyutu (T) yatay kesit boyutu (N)' ndan büyük olduğu durumda yani $T>N$ için Breusch-Pagan (1980) tarafından geliştirilen CDLM1 testi kullanılmaktadır. Hem $T$ hem de $N$ büyük olduğu durumlarda Pesaran (2004) tarafından geliştirilen CDLM2 testi uygulanabilmektedir. $T<N$ olduğu durumlarda ise Pesaran, Yamagata (2008) tarafından geliştirilen CDLM testi (Cross Section Dependent Test) ile birimler arasında yatay kesit bağımlılı̆̆ araştırılmaktadır (Hepaktan ve Çınar, 2011, s. 142). Çalışmada 2004-2019 dönemini kapsayan 16 yıl ( $T$ ) ve Türkiye' de İstatistiki Bölge Birimleri Sınıflamasına göre 26 alt bölge $(N)$ bilgilerine dair $(T<N)$ özellikler dikkate alınarak yatay kesit bağımlılığı araştırmasında Pesaran, Yamagata (2008) tarafından çalışılan CDLM testi uygun bulunmuştur. Test bilgisi denklem (3)' de verildiği gibidir. (Recepoğlu, Doğanay ve Değer, 2020, s. 74):

$$
C D_{L M}=\left(\frac{2}{N(N-1)}\right)^{1 / 2} \sum_{i=1}^{N-1} \sum_{j=i+1}^{N} T_{i j} \hat{\rho}_{i j} \rightarrow N(0,1)
$$


Homojenlik araştırmasına göre, eğim katsayılarının homojenliği üzerine yapılan ilk çalışma Swamy (1970) tarafından yapılmıştır. Eğim parametrelerinde homojenliği araştırmak için Pesaran ve Yamagata (2008) tarafından geliştirilen homojenlik testi (Slope Homogencity Test) uygulanmakta ve (4) nolu denklemde bağımsız değişken parametresi $\beta$ (eğim katsayısı) birimlerin homojen olup olmadığını sinamaktadır.

$$
\begin{aligned}
& Y_{i t}=\alpha+\beta_{i} X_{i}+\varepsilon_{i t} \\
& \widetilde{\Delta}=\sqrt{N}\left(\frac{N^{-1} S-k}{2 k}\right) \sim \chi_{k}^{2} \\
& \widetilde{\Delta}_{a d j}=\sqrt{N}\left(\frac{N^{-1} \bar{S}-k}{v(T, k)}\right) \sim N(0,1)
\end{aligned}
$$

Denklem (5) test istatistiği büyük örneklemler için kullanılırken, denklem (6) test istatistiği küçük örneklemlerde kullanılmaktadır. Burada: $N$; birim sayısı, $S$; swamy test istatistiği, $k$; açıklayıcı değişken sayısı ve $v(T, k)$ standart hata olarak iade edilmektedir (Recepoğlu, Doğanay ve Değer, 2020, s. 74).

Zaman boyutu içeren serilerde analizler çalışılmadan önce, model tahminlerinde kullanılacak serilerin zaman içerisindeki durağanlıklarının araştırılması gerekmektedir. Durağanlığın araştırılmasında birim kök testleri kullanılmaktadır (Yıldırım ve Yaşa, 2014, s. 486). Yatay kesit bağımlılığı test sonuçlarına göre serilerin durağanlıklarının araştırılmasında ikinci nesil birim kök testlerinin kullanılması gerekli görülmüştür. İkinci nesil birim kök testlerinde, $T<N$ durumuna uygun birim kök testi Pesaran (2007) tarafından sabitli modele göre çalışlan CADF testi uygun gelmektedir. Bu test, veri setinde birimler arasında yatay kesit bağımlılığı bulunduğu durumlarda kullanılabilen ikinci nesil birim kök testlerindendir. CADF testinde, Genişletilmiş DickeyFuller tahmininden sağlanmış gecikmeli yatay kesit ortalamaları dikkate alınmaktadır. Böylede ADF regresyonunda birinci fark alınarak, yatay kesit bağımlılı̆̆ı giderilir. CADF denklemi aşağıda verildiği gibidir (Tatoğlu, 2013, s. 223):

$$
\Delta Y_{i, t}=\alpha_{i}+\rho_{i} Y_{i t-1}+d_{0} \bar{Y}_{t-1} d_{1} \bar{Y}_{t}+\varepsilon_{i t}
$$


CIPS istatistiği gecikmeli değişkenlerin t-istatistiklerinin ortalamalarıyla hesaplanır. CIPS testinde bulunan kritik değerler kesit sayıları için hesaplanabilir. Testin asimtotik limiti standart değildir. CIPS istatistiğine ait denklem aşağıda verilmektedir (Recepoğlu, vd. 2020, s. 75).

$$
C I P S=C A D F_{i}=\frac{\sum_{i=1}^{N} C A D F_{i}}{N}
$$

Eşbütünleşme testi, birim kök testlerinden sonra uzun dönemde seriler arasında karşılıklı bir ilişkinin var olup olmadığının incelendiği bir testtir. Westerlund (2007), değişkenler arasındaki eşbütünleşme ilişkisini incelenmek amacıyla hata düzeltme modelli dört adet panel eşbütünleşme testi üzerinde çalışmıştır. Bu testlerden $G$ t ve $G a$ panelin heterojen olması durumunda yorumlanan grup ortalama istatistiklerini vermektedir, $P t$ ve $P a$ ise panelin homojen olması durumunda yorumlanan panel istatistiklerini vermektedir (Tatoğlu, 2017, s. 200-203). Westerlund panel eşbütünleşme testinde, panelin heterojen olması durumunda $G t$ ve $G a$ istatistikleri dikkate alınmaktadır. Chang (2004)' deki çalışmasında, panel veri setinde birimler arasında yatay kesit bağımlılığı olması durumunda dirençli olasılık değerlerinin kullanılmasını önermektedir. Dumitrescu Hurlin panel nedensellik analizi ise panelde yer alan birimler arasında yatay kesit bağımlılığı bulunması, zaman boyutunun kesit boyutundan hem küçük olması hem büyük olması durumunda da kullanılabilmesi ve dengesiz panel veri setlerinde de kullanılabilmesi gibi unsurlar bakımından çokça tercih edilmektedir (Dumitrescu ve Hurlin, 2012, s. 1457).

\section{Örneklem}

Çalışmada, 2004-2019 yılları arası Vergi Gelirleri (VG) ve Kişi Başına Düşen Gayrisafi Yurtiçi Hasıla (KBGSYH) veri setleri kullanılmıştır. Çalışmanın kesit boyutunu ise, İBBS'de Düzey-2-Türkiye 26 bölge sinfflaması oluşturmuştur. Çalışmada kullanılan veri setleri Türkiye İstatistik Kurumu (TÜİK) ve T.C. Hazine ve Maliye Bakanlığı Muhasebat Genel Müdürlüğü resmi internet sayfalarından sağlanmıştır. Veri setleri 2009=100 baz yılı esas alınarak, Bin TL üzerinden hazırlanmıştır. Hesaplamalarda kolaylık sağlamak ve varsayımlardan sapmaları önlemek amacıyla veri setlerinin logaritmaları alındıktan 
sonra analizlere geçilmiştir. Değişkenlere ait açıklamalar aşağıda Tablo 1. de gösterilmektedir.

Tablo 1. Çalışmada Kullanılan Değişkenler ve Açıklamalan

\begin{tabular}{lllll}
\hline Değişkenler & Kısaltmalar & Açıklama & Veri Kaynağı & Dönem \\
\hline $\begin{array}{l}\text { Kişi Başına Gayri } \\
\text { Safi Yurtiçi Hâsıla }\end{array}$ & KBGSYH & Bin TL & Türkiye İstatistik Kurumu (TÜİK) & $2004-2019$ \\
\hline Vergi Gelirleri & VG & Bin TL & $\begin{array}{l}\text { T.C. Hazine ve Maliye Bakanlı̆̆ı } \\
\text { Muhasebat Genel Müdürlüğü }\end{array}$ & 2004-2019 \\
\hline
\end{tabular}

Türkiye İstatistik Kurumu (TUIK),

Veri setleri, 2009=100 baz yılı esas alınarak, Bin TL üzerinden hazırlanmıştır. Hesaplamalarda kolaylık sağlamak ve varsayımlardan sapmaları önlemek amacıyla veri setlerinin doğal logaritmaları alındıktan sonra analizlere dahil edilmiştir. Panel geneli değişkenlere ait tanımlayıcı istatistikler aşağıda Tablo 2. de verilmiştir.

Tablo 2. Tanımlayıcı İstatistikler

\begin{tabular}{lllllllll}
\hline \multicolumn{1}{l}{ Tanımlayıcı İstatistikler } & & & & & & \\
\cline { 1 - 5 } & Ortalama & Medyan & Max. & Min. & St.hata & J.B.ists. & Olasilik \\
\hline LKBGSYH & 4.1925 & 4.1950 & 4.9100 & 3.5300 & 0.2854 & 6.8439 & 0.0326 \\
LEH & 5.9720 & 5.8250 & 8.4800 & 4.3800 & 0.7932 & 80.913 & 0.0000 \\
\hline
\end{tabular}

Çalışmada kullanılan ekonometrik model aşağıda (2) nolu eşitlikte gösterildiği gibidir.

$$
L V G_{i t}=\alpha_{i t}+\beta_{1} L K B G S Y H_{i t}+\varepsilon_{i t}
$$

Burada; $\mathrm{i}=1, \ldots \ldots ., \mathrm{N}$ Düzey 2 olarak tanımlanan 26 bölge kesit boyutunu ve $t=1, \ldots \ldots . ., T$ ise zamanı göstermektedir.

\section{Bulgular}

Çalışmada ilk olarak, veri setinde birimler arasında yatay kesit bağımlılığı ve katsayılar arasındaki homojenlik araştırması yapılmıştır. Panel veri setini oluşturan değişkenlerde, ikinci nesil panel birim kök testlerinden olan durağanlık testi için Pesaran (2007) tarafından geliştirilen CADF testi kullanılmıştrr. Durağanlık analizinden sonra değişkenler arasındaki uzun dönem ilişki için Westerlund panel eşbütünleşme testi kullanılarak uzun dönem katsayı tahminleri elde edilmiştir. Akabinde, Dumitrescue Hurlin panel nedensellik testi ile değişkenler arasındaki nedenselliğin yönü araştırılmıştır. 


\section{Yatay Kesit Bă̆ımlılı̆̆ı Ve Homojenlik Testleri}

Pesaran, Yamagata (2008) CDLM testi yokluk (Ho) hipotezi "yatay kesit bağımlılı̆̆1 yoktur", alternatif hipotez ise "yatay kesit bağımlılığı vardır" şeklinde kurulur. Veri setinde birimler arasında yatay kesit bağımlılığ (croossection dependence) olmadığ kabul edilirse birinci nesil olarak ifade edilen birim kök testleri kullanılır. Ancak veri setinde birimler arasında yatay kesit bağımlılığı olduğu yönünde bir tespit, ikinci nesil olarak adlandırılan birim kök testlerini kullanmayı gerektirir. Böylece analiz sonuçları güvenilir, tutarll, etkin ve sağlam tahminler sağlayacaktır(Tatoğlu, 2007: 250).

Tablo 3. Yatay Kesit Bağımlılı̆̆ı Test Sonuçlan

\begin{tabular}{|c|c|c|c|c|}
\hline \multicolumn{5}{|c|}{ Yatay Kesit Bağımlılığı Testi } \\
\hline & \multicolumn{2}{|c|}{ KBGSYH } & \multicolumn{2}{|c|}{ VG } \\
\hline & İstatistik & Olasılık & İstatistik & Olasilik \\
\hline $\mathrm{CDLM}_{1}(\mathrm{BP}, 1980)$ & 813.0963 & $0.0000^{* * *}$ & 559.9151 & $0.0000^{* * *}$ \\
\hline $\mathrm{CDLM}_{2}$ (Pesaran, 2004) & 19.14471 & $0.0000^{* * *}$ & 9.214127 & $0.0000^{* * *}$ \\
\hline $\begin{array}{l}\text { CDLM } \\
\text { vd.2004) }\end{array}$ & -2.450113 & $0.0143^{* *}$ & -2.476757 & $0.0133^{* *}$ \\
\hline Bias-Adjusted CD Test & 18.27804 & $0.0000^{* * *}$ & 8.347460 & $0.0000^{* * *}$ \\
\hline
\end{tabular}

Not: ${ }^{* * *},{ }^{* *},{ }^{*}$ gösterimi sırasıyla $\% 1, \% 5$ ve $\% 10$ düzeylerinde istatistiksel anlamlılığ ifade eder.

Tablo 3. sonuçlarına göre; yatay kesit bağımlılığı için yapılan test sonuçları olasılık değerleri anlamlı olup panel genelinde $\mathrm{Ho}$ hipotezi reddedilmiştir. Birimler arasında yatay kesit bağımlılığı vardır. Bu sonuca göre ikinci nesil olarak tanımlanan birim kök testleri kullanılmalıdır.

Tablo 4. Homojenlik Testi Sonuçları

\begin{tabular}{lllll}
\hline \multicolumn{5}{c}{ Swamy -S Testi-5 } \\
\hline tdvergit & Katsay1 & St.hata & z-istatistik & P> $|z|$ \\
\hline tdkbgsyht & 1.0794 & 0.025 & 42.68 & $0.000^{* * *}$ \\
tddkbgsyht & 0.0213 & 0.137 & 0.16 & 0.876 \\
tddfkbgsyht & 0.0939 & 0.420 & 0.22 & 0.825 \\
tddlkbgsyht & 0.01211 & 0.162 & 0.07 & 0.940 \\
Sabit & 0.0071 & 0.122 & 0.06 & 0.953 \\
\hline Parametre sabitliği testi: & Chi2(90)=2372.21 & Prob > chi2 $=0.000^{* * *}$ \\
\hline
\end{tabular}

Not: ${ }^{* * *},{ }^{* *},{ }^{*}$ sembolleri sirasiyla $\% 1, \% 5$ ve $\% 10$ düzeyinde istatistiksel anlamlılığ 1 ifade eder.

Tablo 4.' de Swamy S testlerinden ikinci kuşak tahmincilerde homojenliğin araştırılmasında kullanılan, öncül ve gecikme uzunluğu 1 olarak alınmış 
test sonuçları verilmektedir. Bu testin yapılabilmesi için önce ilgili değişkenler türetilerek tahminleme yapılmıştır. Homojenlik testi sonuçlarına göre, $\mathrm{Ho}$ hipotezi reddedilmiş ve parametrelerin heterojenliği kabul edilmiştir. Panel çalışmalarında heterojenlik önemli bir faktördür. Panel veri setindeki yatay kesitler farklı niteliklere sahip olabilirler, kısacası kesitler durağan ya da durağan olmama (eşbütünleşik ya da eşbütünleşik olmama) gibi farklılıklar gösterebilirler (Asteriou ve Hall, 2007, s. 366).

\section{Panel birim kök testleri}

Tablo 5. Birim Kök Test Sonuçları (Düzeyde ve 1. Farklarda)

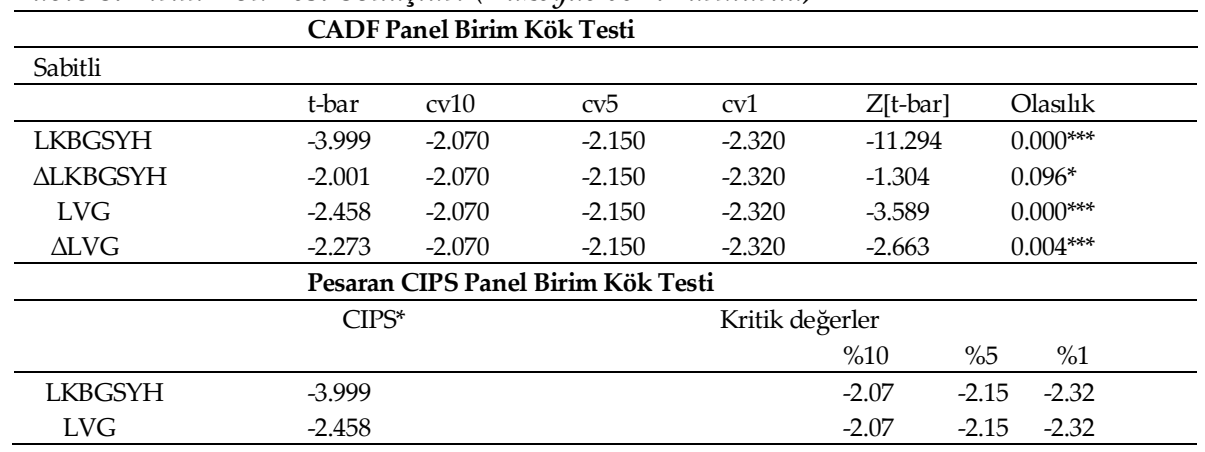

NOT: CADF testi kritik değerleri Pesaran (2007)'ın çalışmasına göre belirlenmektedir. $\Delta$ işareti değişkenlerde birinci fakı ifade etmektedir. ${ }^{* * *},{ }^{* *},{ }^{*}$ sembolleri sırasıyla $\% 1, \% 5$ ve \%10 düzeyinde anlamlılığı ifade eder. Lags (11).

Tabloda verilen bilgiler incelendiğinde, CADF panel birim kök testi sonuçlarına göre LKBGSYH ve LVG değişkenleri hem düzeyde hem de birinci farklarda durağandır. t-bar istatistiği |-3.999|, verilen \%90, \%95 ve \%99 güven düzeyleri için belirtilen kritik değerlerden mutlak değerce büyük olduğu için seri durağandır. Benzer şekilde $Z[t$-bar] istatistiğinin olasılık değerlerine göre serinin durağan olduğu ifade edilebilir. Pesaran' in panel birim kök testi (CIPS test) sonuçları incelendiğinde, CIPS istatistikleri, \%90, \%95 ve \%99 güven düzeylerinde verilen kritik değerlerden mutlak değerce büyük olduğu için seriler durağandır. 


\section{Panel Eşbütünleşme Testleri}

Durağanlık araştırmasından sonra seriler arasında uzun dönemde bir eşbütünleşme ilişkisinin bulunup bulunmadığını araştırmak için Westerlund eşbütünleşme analizi kullanılmıştır.

Tablo 4. Westerlund Eşbütünleşme Test Sonuçlan

\begin{tabular}{lllll}
\hline \multicolumn{5}{c}{$L V_{i t}=\alpha_{i}+\beta_{1} L K B G S Y H_{i t}+\varepsilon_{i t}$} \\
\hline İstatistik & İstatistik & Z-İstatistik & Olasllı & DirençliOlasillk \\
\hline $\mathrm{Gt}$ & -3.982 & -12.555 & $0.000^{* * * *}$ & $0.005^{* * * *}$ \\
$\mathrm{Ga}$ & -15.435 & -7.748 & $0.000^{* * *}$ & $0.005^{* * *}$ \\
$\mathrm{Pt}$ & -15.956 & -8.329 & $0.000^{* * *}$ & 0.220 \\
$\mathrm{~Pa}$ & -11.524 & -7.966 & $0.000^{* * *}$ & 0.160 \\
\hline
\end{tabular}

Not: Westerlund (2007) eşbütünleşme testinde Ho hipotezi “Eşbütünleşme Yoktur” şeklindedir. ${ }^{* * *},{ }^{* * *}$, sembolleri sırasıyla $\% 1, \% 5$ ve $\% 10$ düzeyinde istatistiki anlamlılığ ifade eder. Testte dirençli olasılık değerleri 400 adet bootstrap ile hesaplanmıştır.

Tablo 4.'de verilen Westerlund (2007) panel eşbütünleşme test sonuçlarında $G t$ ve $G a$ istatistiklerinin dirençli olasılık değerlerine göre, "Eşbütünleşme Yoktur" şeklindeki Ho hipotezi istatistiki olarak \%1 anlamlılık düzeyine göre reddedilmektedir. Buna göre değişkenler arasında kuvvetli düzeyde eşbütünleşme ilişkisi vardır. Elde edilen bu sonuçlara göre, Türkiye'de İstatistiki Bölge Birimleri Sınıflaması Düzey 2' de yer alan 26 alt bölgede kişi başı gayri safi yurt içi hasıla ile bu bölgelerde vergi gelirlerinin uzun dönemde birlikte hareket ettiği ifade edilebilir. Uzun dönem katsayılar hem panel geneli için hem de birimler bazında incelenebilir (Yıldırım, 2019, s. 1370). Panel geneli ve birimlere göre ortalama grup dinamik en küçük kareler (DOLSMG) katsayı değerleri Tablo 5. de verilmiştir.

Tablo 5. Panel DOLSMG Sonuçlan

\begin{tabular}{|c|c|c|c|}
\hline \multicolumn{4}{|c|}{$L V G_{i t}=\alpha_{i}+\beta_{1} L K B G S Y H_{i t}+\varepsilon_{i t}$} \\
\hline \multicolumn{2}{|c|}{ İBBS Düzey 2 (Türkiye 26 bölge sınıflaması) } & \multicolumn{2}{|c|}{ DOLSMG } \\
\hline & & Katsayı & t-istatistik \\
\hline \multicolumn{2}{|c|}{ Panel Katsayısı (ortalama grup) } & 0.1767 & $4.044^{* * *}$ \\
\hline TRA1 & Erzurum, Erzincan, Bayburt & 0.0502 & 0.289 \\
\hline TRA2 & Ağrı, Kars, Iğdır, Ardahan & 1.2180 & $2.216^{* *}$ \\
\hline TRB1 & Malatya, Elazı̆̆, Bingöl, Tunceli & -0.3168 & -0.053 \\
\hline TRB2 & Van, Muş, Bitlis, Hakkari & 0.4079 & 0.498 \\
\hline TRC1 & Gaziantep, Adıyaman, Kilis & 1.1890 & $2.291^{* *}$ \\
\hline TRC2 & Şanlıurfa, Diyarbakır & -5.4470 & $-3.356^{* * *}$ \\
\hline TRC3 & Mardin, Batman, Şırnak, Siirt & 1.2780 & $6.118^{* * *}$ \\
\hline TR10 & İstanbul & -1.2080 & $-3.084^{* * *}$ \\
\hline
\end{tabular}




\begin{tabular}{llll}
\hline TR21 & Tekirdağ, Edirne, Kırklareli & -1.9780 & $-6.699^{* * *}$ \\
TR22 & Balıkesir, Çanakkale & 1.0210 & $10.350^{* * *}$ \\
TR31 & İzmir & -2.2850 & $-8.518^{* * *}$ \\
TR32 & Aydın, Denizli, Muğla & 1.1450 & $4.649^{* * *}$ \\
TR33 & Manisa, Afyon, Kütahya, Uşak & 0.6583 & 0.793 \\
TR41 & Bursa, Eskişehir, Bilecik & 3.7960 & $6.001^{* * *}$ \\
TR42 & Kocaeli, Sakarya, Düzce, Bolu, Yalova & -1.7740 & $-2.72^{* * *}$ \\
TR51 & Ankara & 0.3183 & 1.514 \\
TR52 & Konya, Karaman & 0.9308 & $1.698^{*}$ \\
TR61 & Antalya, Isparta, Burdur & 0.2153 & 0.928 \\
TR62 & Adana, Mersin & -0.5836 & -1.015 \\
TR63 & Hatay, Kahramanmaraş, Osmaniye & 6.3700 & $12.000^{* * *}$ \\
TR71 & Kırıkkale, Aksaray, Niğde, Nevşehir, Kırşehir & -2.5900 & $-6.916^{* * *}$ \\
TR72 & Kayseri, Sivas, Yozgat & -2.0250 & -1.584 \\
TR81 & Zonguldak, Karabük, Bartın & 0.3354 & 0.420 \\
TR82 & Kastamonu, Çankırı, Sinop & 2.5760 & $2.269^{* *}$ \\
TR83 & Samsun, Tokat, Çorum, Amasya & 0.6295 & 1.599 \\
TR90 & Trabzon,Ordu, Giresun, Rize, Artvin, Gümüşhane & 0.6687 & 0.937 \\
\hline
\end{tabular}

Not: t-tablo değerleri üzerindeki ${ }^{* * *},{ }^{* *}, *$ işaretler sırası ile $\% 1, \% 5$ ve $\% 10^{\prime}$ da istatistiksel olarak anlamlılı̆̆ı ifade eder.

Panel Ortalama Grup Dinamik En Küçük Kareler (DOLSMG) test sonuçları panel geneli için değerlendirildiğinde LKBSHMG, nin işareti beklenildiği gibi pozitif çıkmış ve istatistiksel olarak \%1 düzeyinde anlamlı bulunmuştur. Bu sonuca göre uzun dönemde LKBGSYH' daki artışlar LVG' ni panel geneli için pozitif yönde etkilemektedir. Panel genelindeki katsayı 0.17 olarak hesaplanmıştır. Yani Türkiye genelinde LKBGSYH' da \%1 lik artış LVG' ni $\% 0.17$ oranında arttıracaktır ve katsayı istatistiksel olarak anlamlı bulunmuştur.

Ekonomik büyümenin vergi gelirleri üzerine olan etkisi için Panel DOLSMG test sonuçları Türkiye Düzey $2^{\prime}$ ye göre 26 bölge sinıflaması üzerinde incelendiğinde TRA1, TRB1, TRB2, TR33, TR51, TR61, TR62, TR72, TR81, TR83 ve TR90'dan oluşan bu 11 alt bölgede sonuçlar anlamsız çıkmış, kalan diğer 15 alt bölgede ise sonuçlar istatistiksel olarak anlamlı çıkmıştır. TRC1-Gaziantep, Adıyaman, Kilis birimine baktığımızda katsayı pozitif ve istatistiksel olarak anlamlı bulunmuştur. Buna göre KBGSYH' da \%1' lik artış bu bölgenin vergi esnekliğini \%1.19 pozitif yönde etkilemektedir. TRC2-Şanlıurfa, Diyarbakır birimi incelendiğinde katsayı negatif ve istatistiksel olarak anlamlı bulunmuştur. Sonuca göre KBGSYH' da \%1' lik artış bu bölgenin vergi esnekliğini $\% 5.45$ azaltmaktadır. 
Benzer şekilde TR10-İstanbul birimi incelendiğinde katsayı negatif ve istatistiksel olarak anlamlı bulunmuştur. Sonuca göre KBGSYH' da \%1' lik artış bu bölgenin vergi esnekliğini \%1.21 negatif yönde etkilemektedir. Aynı benzer etki İzmir bölgesi için de gerçekleşmiştir. TR31-İzmir birimi incelendiğinde katsayı negatif ve istatistiksel olarak anlamlı bulunmuştur. Sonuca göre KBGSYH' da \%1' lik artış bu bölgenin vergi esnekliğini \%2.28 negatif yönde etkilemektedir. TR51-Ankara birimi ise pozitif bir etki ile istatistiksel olarak anlamlılığı oldukça düşük \%15 anlamlılık düzeyinde ifade edilebilir.

\section{Panel nedensellik testi}

Bu testte, Ho temel hipotezine göre değişkenler arasında nedensellik ilişkisi yoktur. Alternatif hipoteze göre ise en az bir yatay kesitte nedensellik ilişkisi vardır şeklinde kurulmaktadır (Gülmez ve Ahmet, 2015, s.27).

Tablo 6. Panel Nedensellik Testi Sonuçları

\begin{tabular}{lllllll}
\hline \multicolumn{7}{c}{ Dumitrescu Hurlin Panel Nedensellik Testi } \\
\hline Nedensellik Yönü & & & W-İstatistik & Z-İstatistik & Olasllık & \\
\hline LKBGSYH & $\rightarrow$ & LVG & 5.13676 & 10.0874 & $0.0000^{* * * *}$ & Nedenidir \\
LVG & $\rightarrow$ & LKBGSYH & 20.3733 & 49.1287 & $0.0000^{* * *}$ & Nedenidir \\
\hline
\end{tabular}

Not: ${ }^{* * *},{ }^{* * *}$ sembolleri sirasıly $\% 1, \% 5$ ve $\% 10$ da istatistiksel anlamlılığ1 ifade etmektedir. Gecikme uzunluğu 1 olarak alınmıştır.

Tablo 6’ da görüldüğü gibi Dumitrescu Hurlin panel nedensellik analizinde, panelin geneli için panel nedensellik sonuçlarına göre LKBGSYH' dan LVG' ne doğru bir nedensellik ve yine LVG' den LKBGSYH' ye doğru bir nedensellik vardır. Dolayısıyla değişkenler arasında çift yönlü bir nedensellik ilişkisi bulunmuştur.

\section{Sonuç}

Vergi uygulamalarının iktisadi ve mali yapıda meydana gelen gerek kısa dönemli konjontürel değişimlere gerekse daha uzun dönemde ortaya çıkan yapısal değişimlere şekillenmesi, söz konusu değişimlere uyarlanması, güncel gelişmeleri kapsaması ve sonuçlarının yakından takip edilmesi son derece önemlidir. İlgili değişimlerin iktisadi, mali ve sosyal yapı üzerinde bir takım etkiler yaratması kaçınılmaz bir gerçektir. Kuşkusuz burada en önemli husus bu değişimlerin yaratacağı olası etkileri yönetebilme becerisidir. Bu bağlamda vergi esnekliği söz konusu değişimlerin yaratacağı olumsuz etkilerin 
derinleşmeden yönetilebilirliği üzerinde belirleyici olan önemli bir değişkendir.

Çalışmada üzerine yoğunlaşılan konu Türkiye pratiğinde ekonomik büyüme ile vergi gelirleri arasındaki korelasyonun niteliğinin ve derinliğinin saptanmasıdır. Bu kapsamda çalışmada İstatistiki Bölge Birimleri Sınıflaması Türkiye' de 26 bölgede 2004-2019 dönemi için ekonomik büyüme ve vergi gelirleri arasındaki ilişki Westernlund eşbütünleşme ve Dumitrescu Hurlin panel nedensellik yöntemleri kullanılarak araştırılmıştır. Çalışmada, 16 yıllık bir zaman boyutunu ifade eden $T, 26$ birimden oluşan kesit sayısı $N$ 'den az olduğu için $(T<N)$ ve birimler yatay kesit bağımlllı̆̆ içerdiği için serilerin durağanlık araştırmasında ikinci nesil birim kök testleri kullanılmıştır. Ayrıca katsayılar için yapılan homojenlik testi sonucuna göre birimlerin sahip oldukları katsayıların heterojen özellikte olduğuna karar verilmiştir.

Seriler arasındaki uzun dönemli ilişki Westernlund eşbütünleşme testi ile incelenmiş ve çalışmada yer alan değişkenler arasında uzun dönemde eşbütünleşme ilişkisi olduğu sonucuna varılmıştır. Ekonomik büyüme ve vergi gelirleri değişkenleri arasında pozitif ve anlamlı bir ilişki tespit edilmiştir. Panel DOLSMG test sonuçları panel bazında değerlendirildiğinde katsayı işareti pozitif ve istatistiksel olarak anlamlı bulunmuştur. Edinilen sonuca göre uzun dönemde ekonomik büyümedeki \%1' lik artıs, vergi gelirlerini panel geneli pozitif olarak uzun dönemde $\% 0.17$ arttırmaktadır. Ekonomik büyümenin vergi gelirleri üzerindeki etkisine dair panel DOLSMG test sonuçları bölgeler bazında incelendiğinde, pozitif vergi esnekliği de negatif vergi esnekliği de görülebilmektedir. Özellikle yüksek nüfuslu ve gelir dağılımda yüksek farlılığa sahip kalabalık bölgelerde negatif /negatife yakın vergi esnekliği görülebilmektedir.

Dumitrescu Hurlin panel nedensellik analizine göre paneli oluşturan değişkenler arasında, hem ekonomik büyümeden vergi gelirlerine hem de vergi gelirlerinden ekonomik büyümeye doğru, çift yönlü bir nedensellik ilişkisi tespit edilmiştir. Bu sonuçlara göre bölgesel bazda kişi başına gayri safi yurt içi hasıla artışı vergi gelirleri üzerinde de artış sağlamaktadır. Vergi esnekliği için anlamlı pozitif katsayı, aynı zamanda verginin gelir sağlama özelliğine ve duyarlılığına işaret etmektedir. 


\title{
EXTENDED ABSTRACT
}

\section{Analysis with Panel Cointegration and Causality Tests of Tax Elasticity in Turkey}

\author{
Zerife Yildırım - Murat Demir \\ Harran Üniversitesi İktisadi ve İdari Bilimler Fakültesi
}

Percentage change of tax revenues in a certain period, the ratio to the percentage change in gross domestic product (GDP) for the same period is expressed as tax elasticity. Tax flexibility, which expresses the sensitivity of tax revenues to changes in gross national product; with its economic, financial and social aspects, it is a field of study on which tax theorists place great emphasis.

According to the Turkish tax system, income-based taxes, expenditurebased taxes and property-based taxes comprise total tax revenues. The subject of income-based taxes consists of two elements: real person income and corporate income. The subject of taxes based on expenses is value added tax, special consumption tax, banking and insurance transactions tax, special communication tax, games of chance tax, taxes collected from international trade and transactions, stamp tax and fees. The subject of propertybased taxes is real estate tax, motor vehicle tax, inheritance and gift tax.

A more general classification can be made in the form of direct and indirect taxes. Accordingly, taxes on income and property can be shown as direct taxes. Indirect taxes, on the other hand, can be shown as taxes levied on expenditures. When examined with this expression $65 \%$ of total tax revenues for Turkey proportionally indirect taxes, 35\% consists of direct taxes.

The purpose of this study is examined for Turkey for periods covering the years 2004-2019 according to Classification of Statistical Territorial Units (IBBS 2) Level 2 of tax flexibility. The shaping of tax practices by both shortterm cyclical changes in the economic and financial structure and structural changes that occur in the longer term, adapting to these changes, cover current developments It is extremely important to closely monitor and its results. It is an inevitable fact that the relevant changes have some effects on 
the economic, financial and social structure. Undoubtedly, the most important point here is the ability to manage the possible effects of these changes. In this context, tax flexibility is an important variable that determines the manageability of the negative effects of these changes without getting deeper. The issue been focused on in the study, in the practice of Turkey is to determine the depth and nature of the correlation between tax revenues and economic growth. In this context, according to Classification of Territorial Units Statistical, was investigated using the econometric methods. For this purpose, Second Generation Unit Root Tests, Westternlund Cointegration and Dumitrescu Hurlin Panel Causality Tests were used. In the study, T, which expresses a 16-year time dimension, it is less than $\mathrm{N}$ number of sections made up of 26 units as $(\mathrm{T}<\mathrm{N})$. Therefore, the units contain cross-sectional dependency the second-generation unit root tests were used in the stationarity research of the series. In addition, according to the homogeneity test result for the coefficients, it was decided that the coefficients of the units are heterogeneous. The results of the analysis showed that the variables of economic growth and tax revenues have a long-term cointegration relationship. The long-term relationship between the series was examined using the Westernlund cointegration test, and it was concluded that there was a long-term cointegration relationship between the variables in the study.

A positive and significant relationship was found between the variables of economic growth and tax revenues.

When the panel DOLSMG test results were evaluated on a panel basis, the coefficient sign was found to be positive and statistically significant. According to the panel DOLSMG test result, the elasticity coefficient for tax revenues across the panel was calculated as 0.17 . According to the result, a $1 \%$ increase in economic growth in the long run increases tax revenues by $0.17 \%$ in the long run. This elasticity value is of a very low quality and cannot fulfill the income generating feature of taxation. When we examine the tax flexibility according to NUTS-Level 2, among 26 regions; the coefficient results of TRA2, TRC1, TRC3, TR22, TR32, TR41, TR63 and TR82 regions were over 1 , positive and statistically significant. When the panel DOLSMG test results on the impact of economic growth on tax revenues are analyzed by regions, positive tax elasticity and negative tax elasticity can be observed. 
It can be observed the negative/close to negative tax flexibility in crowded regions with high population and high-income distribution especially.

In Dumitrescu Hurlin panel causality analysis, there is a causality relationship from economic growth to tax revenues for the panel in general, and again it is seen that there is a causal relationship from tax revenues to economic growth. In other words, it can be stated that there is a bidirectional causality relationship between variables. According to these results, the increase in gross domestic product per capita on a regional basis also increases tax revenues. The significant positive coefficient for tax flexibility also points to the income-generating nature and sensitivity of the tax.

\section{Kaynakça / References}

Akar, S. (2013). Vergi gelirlerinin esnekliği ve istikrar: Merkezi bütçe sınıflandırmasına dayalı ampirik bir analiz. Maliye Dergisi. 165, 27-37.

Akar, S. ve Şahin, Ö. U. (2015). Türkiye' de vergi canlliğının analizi. Journal of Economics, Finance and Accounting (JEFA), 2(1), 29-43.

Asteriou, D. ve Hall, S. G. (2007). Applied econometrics (Rev.ed.). NewYork: Palgrave Macmillan.

Bakanlar Kurulu Kararı (2002). Bölgesel politikalar kararı. https://www.ab.gov.tr/files/SBYPB/B\%C3\%B6lgesel\%20Politika/bakanlar kurulu karari.28.08.2002.doc

Bettendorf, L. ve Van Limbergen, D. (2013). The stability of tax elasticities in the Netherlands. CPB Discussion Paper I, 256, 1-2, 2013.

Bnescua, L. ve Comanniciu, C. (2013). Tax elasticity analysis in Romania: 2001-2012. Procedia Economics and Finance, 6, 614. 609-614.

Bilquees, F. (2004). Elasticity and Buoyancy of the tax system in Pakistan. The Pakistan Development Review, 43(1), 73-93. 25.11.2020).

Bingöl, O. (2020). 2020 Ocak-Haziran dönemi bütçe performansı gerçekleşmeleri. 05.11.2020 tarihinde https://vergiyedair.com/2020/07/18/2020-ocak-haziran-donemi-butcegelir-performansi-gecen-yilin-uzerinde/ adresinden erişilmiştir.

Boschiab, M. ve d'Addona, S. (2017). CAMA Centre for applied macroeconomic analysis the stability of tax elasticities over the business cycle in European countries. CAMA Working Paper, 44, 2.

Breusch, T., Pagan, A. (1980). The Lagrange multiplier test and its application to model specification in econometrics. Rev. Econ. Stud. 47, 239-253.

Bunescu, L. ve Comaniciu, C. (2013). Tax elasticity anaalysis in Romania: 2001-2012. International Economic Conference of Sibiu 2013 Post Crisis Economy: challenges and opportunities. IECS 2013. Procedia Economics and Finance 6, 609-614. 
Chang, Y. (2004). Bootstrap unit root test in panels with cross sectional dependency. Journal of Econometrics. 120(2). 263-293.

Chipeta, C. (1998). Tax reform and tax yield in Malawi. Southern African Institute for Economic Research. The African Economic Research Consortium. AERC Research Paper 81. March 1998. Zomba. Malawi. 20.11.2020 tarihinde https://idl-bncidrc.dspacedirect.org/bitstream/handle/10625/22082/113320.pdf?sequence -1 \&isAllowed $=y$ adresinden erişilmiştir.

Choudhry, N.N. (1979). Measuring the elasticity of tax revenue: A divisia index approach. IMF Econ Rev 26. Staff Papers, 26, 87-122. https://doi.org/10.2307/3866566 https://link.springer.com/article/10.2307/3866566 adreslerinden erişilmiştir.

Çulha, A.A. (2012). Türkiye'de vergi gelirlerinin iktisadi döngülere duyarlılı̆̆. Türkiye Cumhuriyet Merkez Bankası, Çalışma Tebliği, 11(11), 1-25.

Dumitrescu, E. I. ve Hurlin, C. (2012). Testing for granger non-causality in heterogeneous panels. Economic Modelling, 29(4), 1450-1460. 20.05.2020 tarihinde https:/www.sciencedirect.com/science/article/abs/pii/S0264999312000491 adresinden erişilmiştir.

Ertürk, A., Avşar, S. T. ve Bulut, M. (2009). Türkiye verilerine göre vergi canlllı̆̆ı ve esnekliğinin tahmin edilmesi. Ekonomik Yaklaşım. 20(71), 109-119.

Gilles, M. ve Princen, S. (2015). Tax revenue elasticities corrected for policy changes. In the European Economy EU Discussion Paper, 18, 1-3.

Gülmez, A. (2015). OECD ülkelerinde ekonomik büyüme ve hava kirliliği ilişkisi: Panel veri analizi. Kastamonu Üniversitesi İktisadi ve İdari Bilimler Fakültesi Dergisi. 9. 25.05.2020 tarihinde $\quad$ https://dergipark.org.tr/tr/pub/iibfdkastamonu/issue/29618/317937 adresinden erişilmiştir.

Hepaktan, C.E. ve Çınar, S. (2011). OECD ülkeleri vergi sistemi esnekliğinin panel eşbütünleşme testleri ile analizi. Sosyal Bilimler Dergis, 4(2), 133-142.

Kopczu, W. (2005). Tax bases, tax rates and the elasticity of reported income. Journal of Public Economics. 8(11,12). 2093-2119.

Kusi, N. K. (1998). Tax reform and revenue productivity in Ghana. Research Paper SeventyFour March 1998. African Economic Research Consortium. 15.10.2020 tarihinde https://opendocs.ids.ac.uk/opendocs/bitstream/handle/20.500.12413/2210/RP\%2074.pdf?sequence $=1$ adresinden erişilmiştir.

Kuştepeli, Y. veŞapçı, O. (2006). Personal incometax elasticity in Turkey: 1995-2005. Dokuz Eylül Üniversitesi Faculty of Business Department of Economics, Discussion Paper Series. $6(1)$. 1-12. 
Mourre, G., Astarita, C., ve Princen, S. (2014). Adjusting the budget balance for the business cycle: the EU methodology (No. 536). European Economy Economic Papers, 1.38 25.05.2020 tarihinde https://ec.europa.eu/economy finance/publications/economic paper/2014/pdf/ecp536 en.pdf adresinden erişilmiştir.

Mukarram, F. (2001). Elasticity and buoyancy of major taxes in pakistan. Pakistan Economic and Social Review, 39(1), 75-86.

Osoro, N.E. (1993). Revenue productivity implications of tax reform in Tanzania. AERC Research Paper Twenty. Omic Research Consortium. No.20. 15.11.2020 tarihinde https://media.africaportal.org/documents/RP20.pdf adresinden erişilmiştir.

Osoro, N.E. (1995). Tax reforms in Tanzania: motivations, directions and implications. Research Paper Thirty-Eigh. African Economic Research Consortium. https://core.ac.uk/download/pdf/19917827.pdf 15.11.2020

Özmen, İ. (2016). Vergi gelirlerinin belirleyicileri üzerine karşılaştırmalı bir analiz: BRIC-T. Selçuk Üniversitesi İktisadi ve İdari Bilimler Fakültesi Sosyal Ekonomik Araştırmalar Dergisi, 16(32), 233-252.

Pesaran, M.H. (2004). General diagnostic tests for cross section dependence in panels. Cambridge Working Papers in Economics. 435.

Pesaran, M. H. (2007). A simple panel unit root test in the presence of cross-section dependence. Journal of Applied Econometrics, 22, 265-312.

Pesaran, M. H. ve Yamagata, T. (2008). Testing slope homogeneity in large panels. Journal of Econometrics. 142(1), 50-93.

Recepoğlu, M., Doğanay, M. A. ve Değer, M. K. (2020). Enerji tüketimi ile ekonomik büyüme arasındaki ilişkiler: Türkiye'de iller üzerine panel veri analizleri (20042014). Doğuş Üniversitesi Dergisi, 21(1). 69-80.

Russell, S. S. ve Randall, G. (1996). Holcombe measuring the growth and variability of tax bases over the business cycle. National Tax Journal, 49(4), 535-552.

Skeete, R., Coppin, K., Boamah, D. (2003). Elasticities and buoyancies of the Barbados tax system, 1977-1999. Central Bank of Barbados Working Papers, 133-149.

Swamy, P.A.V.B. (1970). Efficient inference in a random coefficient regression model. Econometrica, 38(2). 311-323.

Şimşek, D. (2013). Türkiye'de bölge düzeyinde vergi esnekliği, vergi canllı̆̆̆, vergi kapasitesi ve vergi gayreti.Yayınlanmamış Yüksek Lisans Tezi. Ankara: T.C. Gazi Üniversitesi SBE Ekonometri Anabilim Dalı.

Tatoğlu, F. Y. (2012). Ileri panel veri ekonometrisi: stata uygulamal. İstanbul: Beta Yaynncllı. Tatoğlu, F.Y. (2017). Panel zaman serileri analizi. İstanbul: Beta Basım Yayın Dağıtım A.Ş. Turhan, S. (1987). Vergi teorisi ve politikası. İstanbul: Der. Yayınları, s.318. 
TÜIKK (2020). Türkiye İstatistik Kurumu. 05.09.2020 tarihinde www.tuik.org adresinden erişilmiştir.

Twerefou, D.K., Fumey, A., Assibey, E.O. ve Asmah, E.E. (2010). Buoyancy and elasticity of tax: evidence from Ghana. Journal of Monetary and Economic Integration. 10(2). 15.11.2020 tarihinde http://wami-imao.org/sites/default/files/journals/v10n2unit2.pdf adresinden erişilmiştir.

T.C. Hazine ve Maliye Bakanlığı Muhasebat Genel Müdürlüğü (2020). Anasayfa. 05.09.2020 tarihinde www.muhasebat.hmb.gov.tr adresinden erişilmiştir.

Westerlund, J. (2007). Testing for error correction in panel data. Oxford Bulletin of Economics and Statistics. 69(6), 709-748.

Wolswijk, G. (2007). Short- and long-run tax elasticties. The Case Of The Netherlands, 5.

Ylldırım, Z. ve Yaşa, A.A. (2014). The relation between the budget deficit and energy demand in the selacted european countries and Turkey: panel cointegration analysis. International Journal of Trade, Economics and Finance. 5(6), 482-489.

Yıldırım,Z. (2019). Eğitim harcamaları ileekonomik büyümearasındaki ilişki: ARDLsınır testi yaklaşımı. Journal of Social, Humanities and Administrative Sciences. 5(21).13671375.

Yüce, M. (2004). Verginin mali amacı açısnndan Kurgzz sisteminin geğerlendirilmesi. Mevzuat Dergisi. 7(78). 20.11.2020 tarihinde http://www.basarmevzuat.com/dergi/2004-06/a/04 adresinden erişilmiştir.

\section{Kaynakça Bilgisi / Citation Information}

Yıldırım, Z. ve Demir, M. (2021). Türkiye'de vergi esnekliğinin panel eşbütünleşme ve nedensellik testleri ile analizi. OPUS-Uluslararası Toplum Araştırmaları Dergisi, 17(36), 2714-2739. DOI: 10.26466/opus.848755 